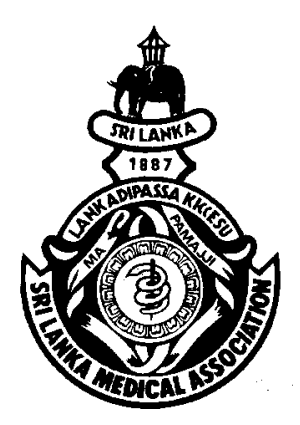

All communications

should be addressed to

The Editors, CMJ

Editors Emeritus

Dr Chris G Uragoda MD, FRCP

Professor Colvin Goonaratna FRCP, PhD

Editors

Janaka de Silva DPhil, FRCP

Anuruddha Abeygunasekera MS, FRCS

\section{Assistant Editors}

Dennis Aloysius MBBS, FCGP

D N Atukorala MD, FRCP

Sarath Gamini de Silva MD, FRCP

S A S Goonawardena MS, FRCS

Dulani Gunasekara MD, MRCP

A Pathmeswaran MBBS, MD

Lalini Rajapakse MD, MSc

Channa Ranasinha MRCP, DTM \& H

Udaya Ranawaka MD, MRCP

Kolitha Sellahewa MD, FCCP

Sivakumar Selliah MBBS, MPhil

Harshalal R Seneviratne DM, FRCOG

Shalini Sri Ranganathan MD, PhD

International Advisory Board

Kamran Abbasi MBChB, MRCP

London, UK

Raja Bandaranayake FRACS, PhD

Sydney, Australia

Peush Sahni MS, PhD

New Delhi, India

R K Tandon MD, PhD

New Delhi, India

Zulfiqar Ahmed Bhutta FRCPCH, PhD

Karachi, Pakistan

Continued overleaf
THE CEYLON

MEDICAL JOURNAL

Established 1887

The Official Publication of the

Sri Lanka Medical Association

Volume 53, No.3, September 2008

Quarterly ISSN 0009-0875

\section{Dengue fever - predictors of disease severity and their influence on management}

\section{Introduction}

The annual global figures for dengue fever (DF) and dengue haemorrhagic fever (DHF) are about 100 million and half a million respectively, and $90 \%$ of the patients are children $<15$ years [1]. Case fatality in Asia is 0.5 - 3.5\% [2]. The first major epidemic in Sri Lanka was in 1989. The dengue pandemic in 1998 led to a resurgence of interest in its prevention and management.

Clearly, early diagnosis and prompt, appropriate treatment of dengue prevent morbidity and mortality [3]. The majority of adult patients with dengue recover completely without specific interventions. It is necessary to identify the minority of patients early in the disease for close monitoring and appropriately timed fluid therapy to prevent progression to dengue shock syndrome (DSS). Achieving this requires the ability to predict disease severity.

\section{Predictors of disease severity}

Dengue viruses undergo replication within cells of mononuclear phagocyte lineage. Infection of mast cells, dendritic cells and endothelial cells also occurs $[4,5,6]$. The ensuing viraemic phase is followed either by recovery or progression to DHF or DSS, which is a consequence of plasma leakage. Peak viraemia correlates with the severity of dengue infection. The pathogenesis of plasma leakage involves a complex interplay of antibody, cytokine and cellular immune responses, and understanding this is necessary for accurate prediction of disease severity.

Secondary dengue infection in the face of sub-neutralising concentrations of dengue antibodies results in the formation of immune complexes. The Fc portion of these antibodies binds to Fc receptor bearing cells. Antibody dependant enhanced infection of target cells leads to increased viral replication. Certain viral strains have an increased ability to replicate in target cells and cause severe clinical disease. Even though antibodies are formed against both structural and non-structural (NS) viral protein after primary infection, antibodies against viral NS 1 have been shown to induce endothelial cell apoptosis. An elevated serum level of NS 1 within 72 hours of the illness identifies patients at risk of developing DHF [7].

Different IgG subclasses vary in their ability to activate the classical complement pathway. Since complement activation could contribute to increased vascular permeability and abnormalities in coagulation, the predominating IgG subclass may also be important in the pathogenesis of severe disease $[8,9]$. Total and dengue specific IgE antibody levels are higher in patients with DHF and DSS compared with those with DF [10]. Anti-platelet 
Samiran Nundy FRCS, FRCP

New Delhi, India

N Medappa MD

New Delhi, India

Jane Smith BA, MSc

London, UK

Anita KM Zaidi MMBS, SM

Karachi, Pakistan

David Warrell MD, FRCP

Oxford, UK

\section{Advisory Board for}

Statistics and Epidemiology

Lalini Rajapakse MD, MSc

Kumudu Wijewardene MBBS, MD

A Pathmeswaran MBBS, MD

\section{Published by}

The Sri Lanka Medical

Association

Wijerama House

6, Wijerama Mawatha

Colombo 7

Sri Lanka

Tel: +94 112693324

Fax: +94 112698802

Internet home page

http://www.cmj.slma.lk

e-mail: office@cmj.sIma.Ik

\section{Printed by}

Ananda Press

82/5, Sir Ratnajothi Saravanamuttu

Mawatha, Colombo 13

Sri Lanka

Tel: +94 112435975

Fax: +94 112385039

e-mail: anpress@sItnet.lk

(c) The Ceylon

Medical Journal

This journal is indexed in BIOSIS, CAB

International, EMBASE, and

Index Medicus antibodies are found in higher concentrations in patients with DHF and DSS compared to DF, and anti-platelet antibodies cause lysis of platelets in the presence of complement [11]. Induction of thrombocytopenia and the severity of the disease in secondary dengue virus infections are determined by plateletassociated immunoglobulins involving antidengue virus activity [12]. Humoral immune responses are modulated during infection by an increase in Blymphocytes and a decrease in T-lymphocytes, which is evident in DHF (13).

A variety of cytokines are produced by dengue virus infected monocytes, B-lymphocytes, and mast cells. Increased levels of TNF $\alpha$, IL-6, IL-13 and IL18 have been reported during severe dengue infections. These cytokines have been implicated in causing increased vascular permeability and shock. On the other hand, serum IL-12 levels are highest in patients with DF, but undetectable in patients with grades III and IV DHF [14].

Dengue virus infected dendritic cells produce high levels of TNF $\alpha$ and IFN $\alpha$ but low levels of IL-12. TNF $\alpha$ prolongs dendritic cell survival by upregulating anti-apoptotic factors within it. Prolonged survival of dengue viral infected dendritic cells may contribute towards producing severe dengue infections [15]. Increased levels of TNF $\alpha$ correlate with haemorrhagic manifestations. IL-10, by down-regulating platelet function, contributes to platelet defects associated with dengue infection [16]. Low platelet counts together with high plasma aspartate aminotransferase (AST) levels have been reported in DHF. Normal AST is a strong negative predictor of subsequent DHF [17].

It would be evident that accurate prediction of disease severity in dengue requires information such as viral serotype, serum levels of NS protein 1, IgG subclass, dengue specific and total IgE, serum concentration of antiplatelet antibodies, and levels of cytokines such as TNF $\alpha$, IFN $\alpha$ and IL-10. The lack of such information to clinicians at the point of delivery of care leaves them with no option but to rely on clinical variables to predict disease severity. For example, children with dengue fever who had drowsiness, retro-orbital pain, a positive tourniquet test and platelet counts below $50000 / \mu \mathrm{l}$ were more likely to develop complications [18].

\section{Management}

From a practical point of view, reduction in the morbidity and mortality of dengue resides firstly in early diagnosis and then on the ability to identify early the minority of patients with a propensity to develop severe disease. Diffuse blanching erythema is a very useful sign in the early clinical diagnosis of dengue in adults during epidemics [3,17]. Serological confirmation is not an absolute requirement for management and should be requested if there is a doubt in the diagnosis, specially to differentiate dengue from other febrile illnesses with myalgia such as leptospirosis. Patients with a normal sensorium, good peripheral circulation, bounding pulse, capillary refilling time $<2$ seconds, posterior cervical lymphadenopathy and platelet counts $>50000 / \mu \mathrm{l}$ are likely to make an uneventful recovery, and will only require judicious fluid therapy, usually about $1500 \mathrm{ml}$ of isotonic saline over 24 hours. The vast majority of dengue patients fall into this category. Patients with a pulse pressure of $<20 \mathrm{~mm} \mathrm{Hg}$ and poor capillary refilling will require aggressive fluid therapy to prevent progression to DSS. The volume and quality of fluid infused should be dictated by clinical judgement and changes in clinical variables, particularly pulse pressure, haematocrit and platelet count.

Peripheral pulse, capillary refill time, and pulse pressure are the most important variables on which to base decisions on interventions at all levels of care. However, in difficult and ambiguous situations, seeking additional information on predictors of disease severity and capillary leakage facilitates 
decision making. These include cervical lymphadenopathy, acute right hypochondrial pain and tenderness, retroorbital pain, altered senorium, pleural effusions, ascites, oedematous gallbladder on ultrasonography, positive tourniquet test, platelet count, and AST levels. Cervical lymphadenopathy and normal AST levels are strong negative predictors of dengue fever progressing to DHF or DSS.

Clinicians need to be cautioned against over-zealous fluid therapy in haemodynamically stable patients even in the presence of extensive blotchy erythema, and the above mentioned predictors of disease severity, which imply incipient increase in vascular permeability, as they are vulnerable to fluid overloading and mortality. A dynamic approach is needed, with subtle adjustments to fluid therapy in order to strike the correct balance between fluid therapy to offset a drop in the pulse pressure and slow capillary filling on the one hand, and reduction of fluids to avoid compromising haemodynamics on the other.

Thrombocytopenia is common in dengue. However, neither its usefulness in predicting the development of haemorrhagic complications nor the critical level of thrombocytopenia associated with bleeding have been clearly defined. Compounding the dilemma is the lack of guidelines on its management. Consequently, clinicians tend to try out different regimens of intravenous fluids, plasma, and platelet transfusions, or observe patients without interventions. This has resulted in unnecessary transfers to tertiary care hospitals, as well as irrational platelet transfusions and fluid overloading with complications such as pleural effusion, ascites, and pulmonary oedema. Platelet transfusions are hardly ever required even with counts as low as $10000 / \mu$ l because the circulating platelets are haematologically active and sufficient to prevent bleeding due to thrombocytopenia. The survival of transfused platelets is anyway very short in cases of DSS [19]. In general, platelet transfusions should be given when there are serious haemorrhagic manifestations. Transfusion requirements correlate with the occurrence of bleeding in the gastrointestinal tract but not with the platelet count [20]. There is no place for prophylactic platelet transfusions [21]. There is some evidence that fresh frozen plasma may be a useful and safer therapeutic option than platelet transfusions in selected patients with severe thrombocytopenia early in the disease [22].

\section{Conclusion}

Early recognition of clinical predictors of disease severity, avoiding unnecessary platelet transfusions, and judicious fluid therapy early in the disease are of crucial importance in the management of dengue. Clinical variables such as pulse pressure, capillary refill time and haematocrit play a vital role in selection of patients for interventions as well as optimisation of fluid therapy to reduce morbidity and mortality.

\section{References}

1. World Health Organization. Prevention and control of dengue and dengue haemorrhagic fever: comprehensive guidelines. WHO regional publication, SEARO, No. 29, 1999.

2. Halstead SB. Is there an inappropriate dengue explosion? Lancet 1999; 353: 1100-1.

3. Malavige GN, Fernando S, Fernando DJ, Seneviratne SL. Dengue viral infections. Postgraduate Medical Journal 2004; 80: $588-601$.

4. King CA, Marshall JS, Alshurafa H, Anderson R. Release of vasoactive cytokines by antibody enhanced dengue virus infection of a human mast cell/basophil line. Journal of Virology 2000; 74: 7146-50.

5. Jin Jun Ho, Wang JJ, Shaio MF, Chuan Liang Kao, Deh Ming Chang, Shou-Wha Han, Jenn-Haung Lai. Infection of human dendritic cells by dengue virus causes cell maturation and cytokine production. Journal of Immunology 2001; 166: 1499-506.

6. Huang YH, Lei HY, Liu HS, Lin YS, Liu CC, Yeh TM. Dengue virus infects human endothelial cells and induces IL-6 and Il-8 production. American Journal of Tropical Medicine and Hygiene 2000; 63: 71-5.

7. Libraty DH, Young PR, Pickering D, Endy TP, Kalayanarooj S, Green S, Vaughn DW, Nisalak A, Ennis FA, Rothman AL. High circulating levels of the dengue virus non-structural protein NS 1 early in dengue illness correlate with the development of dengue haemorrhagic fever. Journal of Infectious Diseases 2002; 186: 1165-8.

8. Koraka P, Suharti C, Setiati TE, Mairuhu ATA, Gorp EV, Hack CE, Juffrie M, Sutaryo GM, Meer VD, Groen J, Osterhaus DME. Kinetics of dengue virus specific immunoglobulin classes and subclasses correlate with clinical outcome of infection. Journal of Clinical Microbiology 2001; 39: 4332-8.

9. Thein S, Aaskov J, Myint TT, Shew TN, Saw TT, Zaw A. Changes in levels of anti-dengue virus IgG subclasses in patients with disease of varying severity. Journal of Medical Virology 1993; 40: 102-6.

10. Koraka P, Murgue B, Deparis X, Setiati TE, Suharti C, Eric CM, Gorp V, Hack CE, Osterhaus ADME, Groen J. Elevated levels of total and dengue virus specific immunoglobulin $\mathrm{E}$ in patients with disease of varying severity. Journal of Medical Virology 2003; 70: 91-8.

11. Lin CF, Lei HY, Liu CC, Liu HS, Yeh TM, Wang ST, Yang TI, Sheu FC, Kuo CF, Lin YS. Generation of IgM anti platelet autoantibody in dengue patients. Journal of Medical Virology 2001; 63: 143-9.

12. Saito M, Oishi K, Inoue S, Dimaano EM, Alera MTP, Robles AMP, Estrella BD Jr, Kumatori A, Moji K, Alonzo MT, Buerano CC, Matias RR, Morita K, Natividad FF, Nagatake T. Association of increased platelet associated immunoglobulins with thrombocytopenia and the severity of disease in secondary dengue virus infections. Clinical and Experimental Immunology 2004; 138: 299-303.

13. Gilbreath MJ, Pavanand K, MacDermott RP, Ussery M, Burke DS, Nimmannitya S, Tulyayon S. Cold reactive immunoglobulin $\mathrm{M}$ antilymphocyte antibodies directed against $\mathrm{B}$ cells in Thai children with dengue haemorrhagic fever. Journal of Clinical Microbiology 1983; 17: 672-6. 
14. Mustafa AS, Elbishbishi EA, Agarwal R, Chaturvedi UC. Elevated levels of interleukin-13 and IL-18 in patients with dengue haemorrhagic fever. FEMS Immunology and Medical Microbiology 2001; 30: 229-33.

15. Ho LJ, Wang JJ, Shaio MF, Kao CL, Chang DM, Han SW, Lai JH. Infection of human dendritic cells by dengue virus causes cell maturation and cytokine production. Journal of Immunology 2001; 166: 1499-506.

16. Azeredo EL, Zagne SM, Santiago MA, Gouvea AS, Santana AA, Neves-Souza PC, Nogueira RM, Miagostovich MP, Kubelka CF. Characterisation of lymphocyte response and cytokine patterns in patients with dengue fever. Immunobiology 2001; 204: 494-507.

17. Jacobs M. Dengue. Medicine International 2005; 5: 46-8.
18. Narayanan M, Aravind MA, Ambikapathy P, Prema R, Jeyapaul MP. Dengue fever - clinical and laboratory parameters associated with complications. Dengue Bulletin 2003; 27 : 108-15.

19. Isarangkure $P$, Tuchindo $S$. The behaviour of transfused platelets in dengue haemorrhagic fever. South East Asian Journal of Tropical Medicine and Public Health 1993; 24 (Suppl 1): 222-4.

20. Chuansumrit A, Phimolthares V, Tardtong P, TapanevaOlarn C, Tapaneva-Olarn W, Kowasathit P, Chantaroisiri T. Transfusion requirements in patients with dengue haemorrhagic fever. South East Asian Journal of Tropical Medicine and Public Health 2000; 31: 10-4.

21. Guidelines on clinical management of dengue fever/ dengue haemorrhagic fever. Epidemiology Unit Ministry of Health $2005 ; 1-19$.

Kolitha H Sellahewa, Consultant Physician, National Hospital of Sri Lanka, Colombo.

Correspondence: KHS, e-mail: <kolithah@gmail.com>. Competing interests: none declared.

\section{Each man kills the thing he loves}

Yet each man kills the thing he loves, By each let this be heard,

Some do it with a bitter look, Some with a flattering word,

The coward does it with a kiss, The brave man with a sword!

Some kill their love when they are young, And some when they are old;

Some strangle with the hands of lust, Some with the hands of gold:

The kindest use a knife, because The dead so soon grow cold

Some love too little, some too long, Some sell, and others buy;

Some do the deed with many tears, And some without a sigh:

For each man kills the thing he loves, Yet each man does not die.

He does not die a death of shame On a day of dark disgrace,

Nor have a noose about his neck, Nor a cloth upon his face,

Nor drop feet foremost through the floor Into an empty space.

From: The Ballad of Reading Gaol. Oscar Wilde, Irish playwright, poet, epigrammatist and essayist (1856 - 1900) 